\title{
Seroepidemiology of gastritis in Japanese and Dutch working populations: evidence for the development of atrophic gastritis that is not related to Helicobacter pylori
}

\author{
R J Schlemper, S D J van der Werf, J P Vandenbroucke, I Biemond, C B H W Lamers
}

Departments of Internal Medicine, Clinical Epidemiology, and Gastroenterology, University Hospital,

Leiden, the

Netherlands

R J Schlemper

J P Vandenbroucke

I Biemond

C B H W Lamers

Department of Internal Medicine, Westeinde Hospital, The Hague, the Netherlands

S D J van der Werf

Correspondence to: Dr R J Schlemper, Department of Internal Medicine, University Hospital, Building 1, C1-R41, PO Box 9600, 2300 C1-R41, PO Box 9600,2300
RC Leiden, the Netherlands. Accepted for publication 7 December 1994

\begin{abstract}
Serological markers of gastritis, like pepsinogen $A$, pepsinogen $C$, gastrin, and Helicobacter pylori antibodies, can be used to explore the state of the gastric mucosa in populations with contrasting cancer risks. A decreasing pepsinogen A:C ratio and an increasing serum gastrin are known to reflect an increasing severity of atrophic corpus gastritis, which is a precursor of gastric cancer. In 723 subjects (without gastroduodenal surgery) from Japanese $(n=225)$ and Dutch $(n=498)$ working populations, which had a similar composition of age (mean 48 years), sex (male to female ratio $6: 1$ ), and type of occupation, fasting serum samples were analysed for IgG antibodies to $H$ pylori, pepsinogen $A$, pepsinogen $C$, and gastrin in the same laboratory. $H$ pylori infection was significantly more prevalent in the Japanese than in the Dutch $(\mathbf{7 4 . 7 \%}$ and $31 \cdot 3 \%$ ); as was a very low pepsinogen $A$, indicative of severe mucosal atrophy $(4 \cdot 4 \%$ and $1 \cdot 6 \%$ ). Among subjects with and without severe mucosal atrophy the $H$ pylori seropositivity rate was similar. Between the Japanese and the Dutch there were significant differences in mean gastrin (31.8 and 13.4 pmol//) and pepsinogen A:C ratio $(1.7$ and $2 \cdot 9)$. These intercountry differences were as great for $H$ pylori negative subjects (gastrin: 23.7 and $10.3 \mathrm{pmol} /$, pepsinogen A:C ratio: 2.4 and 3.2 ) as for $H$ pylori positive subjects (gastrin: 34.6 and $20.1 \mathrm{pmol} / \mathrm{h}$, pepsinogen $A: C$ ratio: $1 \cdot 5$ and $2 \cdot 5$ ). The intercountry difference in gastrin nearly disappeared after stratification into categories of pepsinogen $A: C$ ratio. In conclusion, the intercountry differences in pepsinogen $A: C$ ratio and
\end{abstract}

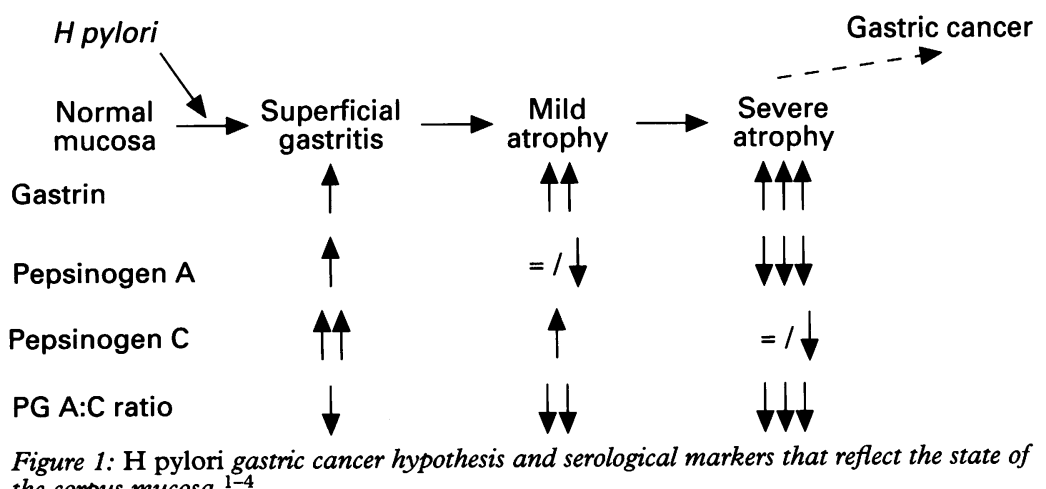

gastrin reflect a higher prevalence of mild and severe mucosal atrophy of the corpus in the Japanese than in the Dutch, both among $H$ pylori positive and negative subjects. Thus, these findings suggest that in the Japanese the development of atrophic gastritis is in part unrelated to $H$ pylori. (Gut 1995; 37: 199-204)

Keywords: atrophic gastritis, gastric cancer, Helicobacter pylori, pepsinogen, epidemiology.

Measuring serum pepsinogens, gastrin, and Helicobacter pylori antibodies can be a patient friendly, cheap, and powerful way of obtaining information about the stomach in large population based studies, this in contrast with performing endoscopies with biopsy specimens. Gastrin and the pepsin precursors pepsinogen $A$ and $C$ are indicative of the histological state of the gastric mucosa (Fig 1). ${ }^{1-4}$ In general, serum gastrin is increased in atrophic corpus gastritis, as the tendency to hypochlorhydria stimulates the $G$ cells in the antrum to produce more gastrin..$^{4-9}$ In contrast, the pepsinogen A:C ratio decreases with a greater severity of atrophy, ${ }^{1-4}$ as pepsinogen $\mathrm{A}$ decreases comparatively more than pepsinogen $C$ because pepsinogen $\mathrm{A}$ is produced only in the corpus while pepsinogen $C$ is also produced in the proximal duodenum, antrum, and cardia.

There has long since been a hypothesis that chronic superficial gastritis may progress through mild through to severe atrophic gastritis. ${ }^{9-11}$ Atrophic gastritis has been shown to be a premalignant lesion. ${ }^{9-15}$ This hypothesis is therefore pivotal in the human model of gastric carcinogenesis (Fig 1). ${ }^{16}$ Since the discovery that $H$ pylor induces chronic superficial gastritis, the hypothesis has led to the question as to whether gastric carcinoma is, in part, the result of an infectious disease. ${ }^{17}$ In recent years the $H$ pylori gastric cancer hypothesis has been tested by patient control investigations ${ }^{18-22}$ and geographical correlation studies 2324 using serology to determine $H$ pylori infection.

In a study performed in Japan and the Netherlands, two countries with contrasting gastric cancer risks, ${ }^{23} 25$ we used $H$ pylori serology, pepsinogens and gastrin, measured in the same laboratory, as a 'biochemical biopsy' indicative of the gastric mucosal histology. We investigated whether Japan, a country with a high gastric cancer risk, showed a higher 
TABLE I Means and 95\% confidence intervals (CI) of pepsinogens in the Fapanese and the Dutch, subdivided by $\mathrm{H}$ pylori status

\begin{tabular}{|c|c|c|c|c|c|c|c|c|}
\hline & \multicolumn{2}{|l|}{ No (\%) } & \multicolumn{2}{|c|}{ Pepsinogen $A(\mu g /)$} & \multicolumn{2}{|c|}{ Pepsinogen $C(\mu g / l)$} & \multicolumn{2}{|c|}{ Pepsinogen A:C ratio } \\
\hline & Fapanese & Dutch & Fapanese & Dutch & fapanese & Dutch & fapanese & Dutch \\
\hline$H$ pylori negative & $57(25)$ & $342(69)^{\star}$ & & & & & & \\
\hline $\begin{array}{l}\text { Mean } \\
\text { 95\% CI } \\
\text { H pylori positive }\end{array}$ & $168(75)$ & $156(31)$ & $\begin{array}{l}40 \cdot 9 \\
36 \cdot 5 \text { to } 45 \cdot 3\end{array}$ & $\begin{array}{l}44.9 \\
42.9 \text { to } 46.9\end{array}$ & $\begin{array}{l}20 \cdot 7 \\
17 \cdot 1 \text { to } 24 \cdot 3\end{array}$ & $\begin{array}{l}15 \cdot 1 \dagger \\
14 \cdot 4 \text { to } 15 \cdot 8\end{array}$ & $\begin{array}{l}2 \cdot 36 \\
2 \cdot 11 \text { to } 2 \cdot 61\end{array}$ & $\begin{array}{l}3 \cdot 16 \ddagger \\
3 \cdot 04 \text { to } 3 \cdot 27\end{array}$ \\
\hline $\begin{array}{l}\text { Mean } \\
95 \% \text { CI } \\
\text { Whole population }\end{array}$ & $225(100)$ & $498(100)$ & $\begin{array}{l}51 \cdot 3 \\
48 \cdot 1 \text { to } 54 \cdot 5\end{array}$ & $\begin{array}{l}58 \cdot 7 \dagger \\
54 \cdot 5 \text { to } 62.9\end{array}$ & $\begin{array}{l}37 \cdot 9 \\
34 \cdot 8 \text { to } 41 \cdot 1\end{array}$ & $\begin{array}{l}26 \cdot 4 \ddagger \\
24 \cdot 0 \text { to } 28 \cdot 7\end{array}$ & $\begin{array}{l}1.52 \\
1.42 \text { to } 1.61\end{array}$ & $\begin{array}{l}2 \cdot 45 \ddagger \\
2 \cdot 30 \text { to } 2 \cdot 60\end{array}$ \\
\hline $\begin{array}{l}\text { Mean } \\
95 \% \text { CI }\end{array}$ & & & $\begin{array}{l}48 \cdot 7 \\
45 \cdot 9 \text { to } 51 \cdot 4\end{array}$ & $\begin{array}{l}49 \cdot 2 \\
47 \cdot 2 \text { to } 51 \cdot 2\end{array}$ & $\begin{array}{l}33.6 \\
30.9 \text { to } 36.3\end{array}$ & $\begin{array}{l}18 \cdot 6 \ddagger \\
17 \cdot 6 \text { to } 19 \cdot 6\end{array}$ & $\begin{array}{l}1.73 \\
1.63 \text { to } 1.84\end{array}$ & $\begin{array}{l}2.94 \ddagger \\
2.84 \text { to } 3.03\end{array}$ \\
\hline
\end{tabular}

Significance of difference between the Japanese and the Dutch: ${ }^{\star} \mathrm{p}<0.001\left(\chi^{2}\right.$ test), $\nmid \mathrm{p}<0.01, \neq \mathrm{p}<0.001$ (Student's $t$ test). All differences between $H$ pylori negative and positive subjects within each population are significant: $p<0.001$ (Student's $t$ test).

prevalence of $H$ pylori induced superficial gastritis as well as gastric mucosal atrophy than a fourfold lower risk country such as the Netherlands. Moreover, we examined to what extent the presence of mucosal atrophy was dependent on $H$ pylori seropositivity.

\section{Methods}

\section{Populations}

Details of the subjects studied have been published elsewhere. ${ }^{26}$ Briefly, the source of participants were companies in The Hague and Eindhoven, the Netherlands, in which $80-90 \%$ of employees regularly undergo periodic medical examinations and Japanese companies where the employees undergo periodic medical examinations in the specialised departments of two private hospitals in Fukuoka. In Japan companies are legally obliged to give employees yearly medical examinations from the age of 35 years. In both the Netherlands and Japan almost all employees (95\% and $99 \%$ ) who came for their medical examinations were willing to participate in the study. In the Netherlands, eight employees $(1 \%)$ were not included because they had a different ethnic origin than white Dutch subjects.

During a four month period at the end of 1988 (Japan) and of 1991 (the Netherlands) 196 men and 35 women from Japan and 427 men and 73 women from the Netherlands participated in the study, in total 731 employees, aged 22-71 years. Two Dutch and five Japanese male ulcer patients and one Japanese male gastric cancer patient were excluded because of gastroduodenal surgery. Thus, 723 subjects form the basis of this report. As the male to female ratio was $6: 1$ in both the Japanese and the Dutch, we did not separate the women from the men when comparing the Japanese with the Dutch. They were similar with regard to socioeconomic status as reflected by their occupations: the ratio of white to blue collar workers was $2: 1$ in both countries. The study was approved by the local review committees of the participating centres and subjects gave informed consent.

\section{Serum measurements}

Blood samples were obtained after an overnight fast; they were centrifuged, coded, and stored at $-20^{\circ} \mathrm{C}$ until simultaneous determination of anti- $H$ pylori $\mathrm{IgG}$, pepsinogen $\mathrm{A}$, pepsinogen $\mathrm{C}$, and gastrin.

IgG antibodies to $H$ pylori were measured by a modified enzyme linked immunosorbent assay, which has previously been described in detail. ${ }^{27}$ The sensitivity and specificity of this assay in diagnosing $H$ pylori infection are both $97 \% .^{28}$

Pepsinogen A and C were measured by radioimmunoassay as previously described and the pepsinogen A:C ratio was calculated. ${ }^{29}$ Their normal ranges in our laboratory are 19-95 $\mu \mathrm{g} / 1$, up to $24 \mu \mathrm{g} / 1$ and $2 \cdot 1$ or higher, respectively, as defined in $H$ pylori negative blood transfusion donors. ${ }^{30}$ Severe chronic atrophic gastritis that has led to achlorhydria was estimated by a serum pepsinogen $A$ value lower than $17 \mu \mathrm{g} /$ l. $^{62431}$ The accuracy of this estimation is illustrated by the fact that half of the subjects with a pepsinogen $\mathrm{A}<17 \mu \mathrm{g} / \mathrm{l}$ also had a very high gastrin value $(>80 \mathrm{pmol} / \mathrm{l}),{ }^{8}$ on average $200 \mathrm{pmol} / \mathrm{l}$, showing severe atrophic gastritis affecting mainly the corpus, while their mean pepsinogen $\mathrm{A}: \mathrm{C}$ ratio was very low: $0 \cdot 4$.

Serum gastrin was measured by a sensitive and specific radioimmunoassay as previously described. ${ }^{32}$ The normal range of gastrin in our laboratory is up to $40 \mathrm{pmol} / \mathrm{l}$.

\section{Statistical analysis}

All statistics were computed using the Statistical Package for the Social Sciences, SPSS. Prevalence data were compared by the $\chi^{2}$ test with Yates's correction while means were compared by Student's $t$ test. Confidence intervals (CI) for proportions were based on binomial distributions.

\section{Results}

\section{H pylori}

The prevalence of $H$ pylori infection increased with age. In the Netherlands, among those aged 22-39 years, 40-59 years, and 60-71 years the rate of $H$ pylori seropositivity was $11 \%, 35 \%$, and $53 \%$; in Japan it was $59 \%$, $76 \%$, and $82 \%$. Thus $H$ pylori infection was much more frequent in Japan than in the Netherlands among all age groups. In all 498 Dutch (mean age 48.0 ), the rate was $31 \%$ and in all 225 Japanese (mean age $48 \cdot 6$ ) it was $75 \%$ (Table I). 
TABLE II H pylori seropositivity rate among subjects with or without severe mucosal atrophy as shown by a pepsinogen $A$ lower than $17 \mu g /$

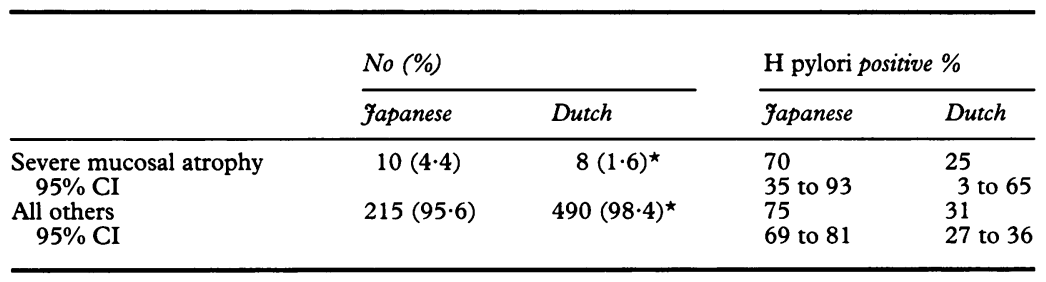

Significance of difference between the Japanese and the Dutch: ${ }^{\star} \mathrm{p}<0.05\left(\chi^{2}\right.$ test).

\section{Pepsinogens}

The prevalence of a very low pepsinogen A value indicative of severe atrophic gastritis was almost three times higher in the Japanese than in the Dutch: $4.4 \%$ and $1.6 \%$ (Table II). Comparing subjects with and without severe mucosal atrophy the $H$ pylori seropositivity rate was similar, both for the Japanese and for the Dutch (Table II).

Among $H$ pylori positive subjects the mean pepsinogen A concentration was significantly lower in the Japanese than in the Dutch (Table I). Among $H$ pylori negative subjects this difference was weaker and not significant. Pepsinogens are higher in $H$ pylori positive subjects than in $H$ pylori negative subjects while the Japanese population consists of more than twice as many $H$ pylori positive subjects as the Dutch. Therefore the mean pepsinogen A concentration was similar when comparing the whole Japanese population with the whole Dutch population.

Pepsinogen $C$ was much higher in the Japanese than in the Dutch, both among $H$ pylori positive and negative subjects (Table I).

As pepsinogen A was slightly lower while pepsinogen $C$ was considerably higher in the Japanese than in the Dutch, the pepsinogen A:C ratio was much lower (Table I). The intercountry difference in pepsinogen $\mathrm{A}: \mathrm{C}$ ratio was almost as great among $H$ pylori negative subjects, as well as positive subjects, as in the whole population (Table I). The higher prevalence of decreased pepsinogen A:C ratios, indicative of atrophic gastritis (Fig 1), among the Japanese compared with the Dutch seems therefore to be independent of $H$ pylori seropositivity.

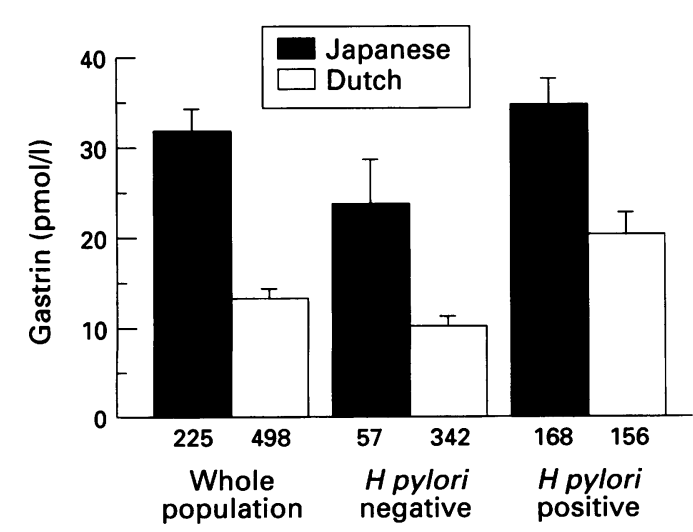

Figure 2: Mean gastrin concentrations in the fapanese and the Dutch, subdivided by $\mathrm{H}$ pylori status. The error bar on top of the columns shows the standard error of the mean. Figures at the bottom of the columns give the number of subjects in each group.
Gastrin

In the Japanese the mean fasting serum gastrin was around twice as high as in the Dutch (Fig 2: $31.8 v 13.4 \mathrm{pmol} / \mathrm{h}, 95 \% \mathrm{CI}: 26.9$ to $36.9 v$ 11.3 to $15.4 \mathrm{pmol} / \mathrm{l})$. The intercountry difference in gastrin among $H$ pylori negative subjects $(23.7 \quad v 10.6 \mathrm{pmol} / \mathrm{l})$ and among $H$ pylori positive subjects $(34.6 v 20 \cdot 1 \mathrm{pmol} / \mathrm{l})$ was as great as in the population as a whole (Fig 2). Therefore, as in Table I for the pepsinogen A:C ratios, Fig 2 shows that the higher prevalence of increased gastrin concentrations, indicative of atrophic gastritis (Fig 1), in the Japanese compared with the Dutch is independent of $H$ pylori seropositivity.

Figure 3 shows that this intercountry difference in gastrin is indeed a reflection of a different prevalence of mucosal atrophy. Figure 3 shows a subdivision into degrees of mucosal atrophy according to categories of pepsinogen $A: C$ ratio. In each category of pepsinogen $A: C$ ratio - that is, per severity of mucosal atrophy there was almost no difference in gastrin between the Japanese and the Dutch. In both populations, however, serum gastrin became higher to a similar extent with a greater severity of mucosal atrophy. The difference between the populations is found in the distribution of the pepsinogen A:C ratios: a lower value than $1 \cdot 3$, pointing to mild to severe atrophic corpus gastritis, was present in $32.4 \%$ of the Japanese and in only $3.6 \%$ of the Dutch.

In Fig 3, $H$ pylori positive and negative subjects are shown together; when analysed separately the near absence of intercountry differences in gastrin was similar, although at slightly different values of gastrin as $H$ pylori positive subjects have a higher mean gastrin than $H$ pylori negative subjects in the range of pepsinogen A:C ratios higher than 1.3 (Fig 4, Fig 5). The distributions were, however, somewhat different: a significantly higher proportion of the $H$ pylori positive subjects had a pepsinogen $\mathrm{A}: \mathrm{C}$ ratio between 0.7 and 2.49 compared with the $H$ pylori negative subjects and a lower proportion had a ratio between $2 \cdot 5$ and 10.5 (Fig 4, Fig 5), as $H$ pylori induced chronic superficial gastritis is associated with a lower pepsinogen A:C ratio (Table I, Fig 1). Besides, the higher proportion of $H$ pylori positive than negative subjects with a low pepsinogen $\mathrm{A}: \mathrm{C}$ ratio between 0.7 and 1.29 (30\% v 9\% for the Japanese and $6 \% v 1 \%$ for the Dutch) reflects a higher prevalence of mild mucosal atrophy among $H$ pylori positive subjects (Fig 1).

\section{Discussion}

This study shows that in Japan, where gastric cancer is known to be much more frequent than in the Netherlands, the mean fasting serum gastrin is higher and the pepsinogen A:C ratio lower irrespective of $H$ pylori seropositivity. These intercountry differences reflect a higher prevalence of mucosal atrophy in the Japanese than in the Dutch. Also, severe atrophic gastritis, as shown by a very low pepsinogen $A$, is more frequent in Japan. In subjects with or without severe mucosal 


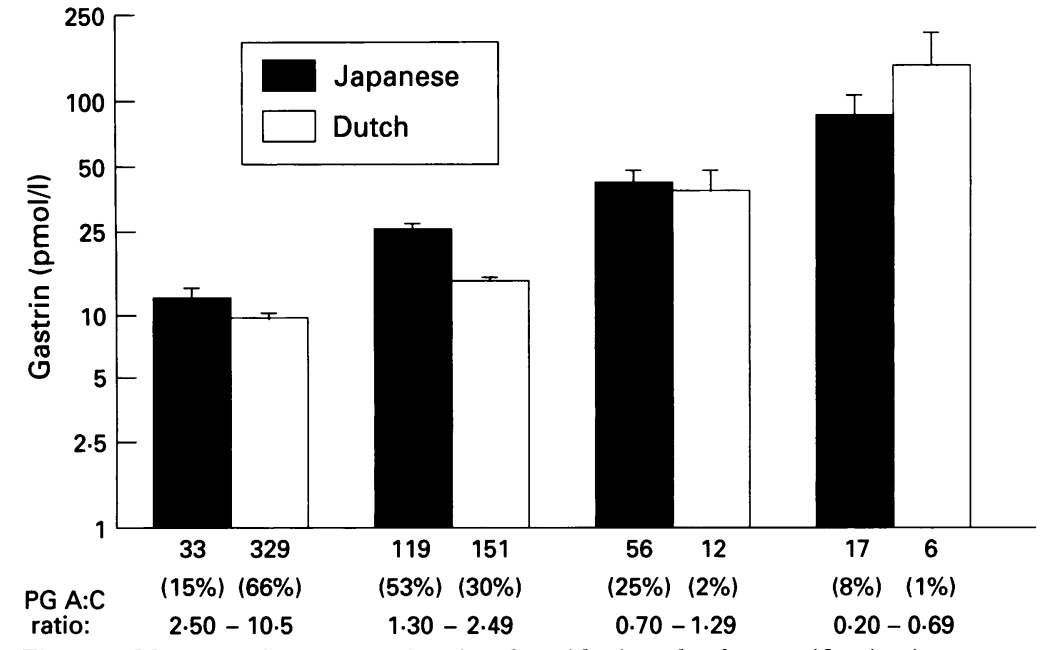

Figure 3: Mean gastrin concentrations in a logarithmic scale after stratification into categories of pepsinogen $A: C$ ratio. At the bottom of the columns the number of subjects in each category is given in figures and percentages of the depicted population.

atrophy the $H$ pylori seropositivity rate is similar. In addition, $H$ pylori seropositivity and thus chronic superficial gastritis is shown to be much more frequent in Japan than in the Netherlands.

The age specific prevalences of $H$ pylori infection we found in the working populations of the Netherlands and in the south of Japan correspond well with those found earlier in the United Kingdom and in the north and the far south of Japan, ${ }^{23} 33$ showing that our findings can be generalised.

A particularly interesting finding was that in the Japanese the higher gastrin and lower pepsinogen $\mathrm{A}: \mathrm{C}$ ratio and thus the higher prevalence of atrophic corpus gastritis were independent of $H$ pylori seropositivity. This points to the fact that for the Japanese population there are other risk factors besides $H$ pylori in the development of atrophic gastritis in the corpus. Otherwise it would be hard to explain why in $H$ pylori negative subjects we still found a large difference between the Japanese and the Dutch.

One explanation could be that these seronegative subjects had been infected by $H$ pylori in the past and that they had become seronegative in the course of developing more

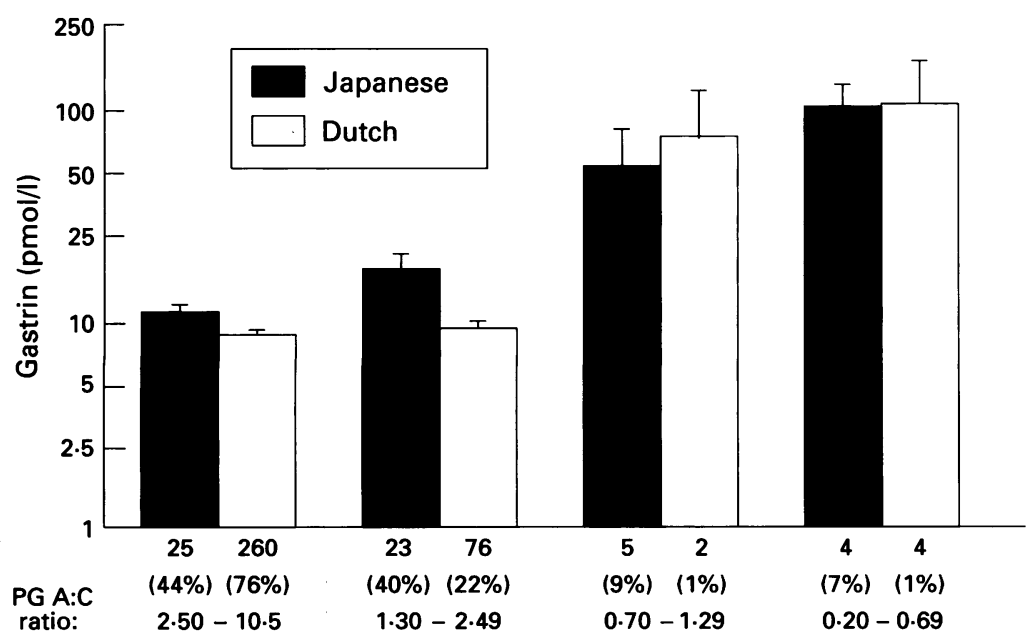

Figure 4: Mean gastrin concentrations in the $\mathrm{H}$ pylori negative subjects after stratification into categories of pepsinogen A:C ratio. Details as described in the legend to Fig 3. severe atrophic gastritis. It is not likely, however, that this often happens as we found that the seropositivity rate of Japanese subjects with severe mucosal atrophy was $70 \%$, which is not lower than in the general population. Besides, a study with a follow up of 10-13 years has shown that subjects who had developed progressive atrophic gastritis remained $H$ pylor seropositive, although the $H$ pylori infection rate as measured by staining of gastric biopsy specimens declined with increasing atrophy. ${ }^{34}$ Also in another study the seropositivity rate in subjects with atrophic corpus gastritis was high while the prevalence of positive staining in the biopsy specimens was low. ${ }^{7}$ So, once subjects are infected, $H$ pylori seropositivity usually remains for life, unless eradication treatment is effectively applied.

Another explanation would be that there is such a genetic difference in gastrin production between the Japanese and white races that at a lesser degree of mucosal atrophy or even in the absence of mucosal atrophy the Japanese have a much higher serum gastrin concentration. In that case the higher gastrin concentration in Japanese $H$ pylori negative subjects would not be a reflection of a higher prevalence of atrophic gastritis. We showed that this is unlikely, however, as the intercountry differences in gastrin nearly disappeared after stratification into categories of pepsinogen A:C ratio, which correspond to certain degrees of severity of mucosal atrophy (Fig 3, Fig 1). ${ }^{1-4}$

Yet another explanation for the higher gastrin concentration in Japanese $H$ pylori negative subjects could be that in many Japanese the atrophic corpus gastritis originated from $H$ pylori negative autoimmune gastritis. In Japan, however, it is well known that autoimmune type $A$ gastritis and pernicious anaemia are extremely rare, much rarer than in Western countries. ${ }^{3}$ Even in Western populations only a few atrophic gastritis cases originate from autoimmune type A gastritis. ${ }^{911-13}$

Therefore, we conclude that in the Japanese population other factors than past $H$ pylori infection play an important part in the development of atrophic corpus gastritis. For example, genetic differences or dietary factors may influence the age and speed of development of atrophic gastritis. ${ }^{152535}$ So the $H$ pylori gastric cancer hypothesis must be complemented for the Japanese population. From our data we are unable to draw a similar conclusion for the Dutch population. There are, however, also studies in Western populations, ${ }^{24} 36$ apart from a Japanese study, ${ }^{37}$ which do not support the view that $H$ pylori is necessary for the development of mucosal atrophy in the corpus. Of course $H$ pylori remains an important factor in the development of atrophic gastritis, as we found a higher proportion of $H$ pylori positive than negative subjects with a pepsinogen A:C ratio between 0.7 and 1.29 (Figs 4 and 5). Pepsinogen A:C ratios this low probably reflect mild atrophic corpus gastritis.

Japanese dietary habits, such as high consumption of nitrite rich salty and pickled vegetables and dried fish, have been associated 


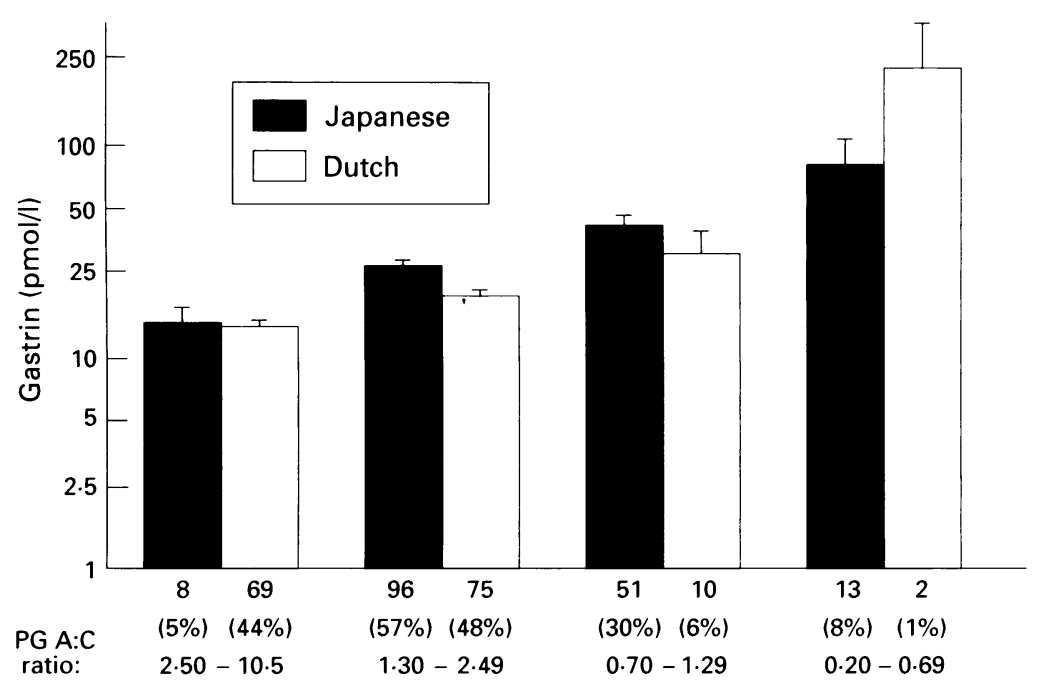

Figure 5: Mean gastrin concentrations in the $\mathrm{H}$ pylori positive subjects after stratification into categories of pepsinogen A:C ratio. Details as described in the legend to Fig 3.

with the development of atrophic gastritis and gastric cancer. ${ }^{152535}$ Also low consumption of fresh fruits and raw vegetables may increase this risk. ${ }^{1525}$ Such dietary habits could be an independent risk factor for atrophic gastritis and could also have a synergistic effect with $H$ pylori. Migrants to countries with lower gastric cancer rates show some diminution of risk. ${ }^{25} 38$ In this respect a comparison of serological markers of gastritis between Japanese people living inside and outside Japan would be interesting. However, such data are not yet available.

Our conclusion of a higher prevalence of atrophic gastritis in the Japanese than in the Dutch is in agreement with a necropsy study comparing stomachs of Japanese and American (Minnesota) people without focal gastroduodenal lesions. ${ }^{14} \mathrm{~A}$ study comparing Japanese and Canadian outpatients using methylene blue dye spraying endoscopy also showed more extensive atrophy in the Japanese in all age groups. ${ }^{39}$ Moreover, in an earlier Japanese study of asymptomatic subjects, who came for routine endoscopy and had no gastroduodenal lesions, ${ }^{40}$ the prevalence of atrophic gastritis was high when compared with Western studies. ${ }^{84142}$

In mild to moderate atrophic corpus gastritis serum pepsinogen $\mathrm{C}$ is increased (Fig 1). This increase may originate from pyloric gland metaplasia of corpus mucosa that has led to an increased number of pyloric glands. ${ }^{140}$ In addition, the release of pepsinogen $C$ from the antrum often occurs at an increased rate because of inflammatory changes. ${ }^{1}$ Serum pepsinogen $\mathrm{C}$ is normal or decreased in severe atrophic gastritis caused by the considerable loss of fundic glands (Fig 1). ${ }^{2}$ The increased pepsinogen $\mathrm{C}$ we found in Japan compared with the Netherlands points to a higher prevalence of subjects with mild and moderate atrophic gastritis. Indeed, the prevalence of severe atrophic gastritis, as shown by a very low pepsinogen $\mathrm{A}$, was comparatively low in our Japanese working population, $4 \cdot 4 \%$. In the Dutch working population we found an even lower prevalence of $1.6 \%$. This is roughly comparable with the presence of achlorhydria in
$2 \cdot 5 \%$ of a similar Western working population reported previously. ${ }^{5}$ Our findings of increased pepsinogen $\mathrm{A}$, pepsinogen $\mathrm{C}$, and gastrin concentrations in $H$ pylori positive compared with negative subjects are in accordance with many previous reports. ${ }^{7243343}$

Points of discussion in this study are the cross sectional study design and the absence of histological data. Using serology instead of biopsy specimens, however, has the advantage of avoiding sampling error, as information is obtained from the stomach as a whole. Besides, performing endoscopies would have practical and ethical problems in a population based study. The strengths of this study include the sampling of representative community populations, the high response rate obtained, the great number of participants, and the good matching with regard to age, sex, and occupation. Moreover, all measurements were carried out simultaneously in the same laboratory. We were therefore able to show for the first time that a country with a high gastric cancer risk has a great number of citizens with a high fasting serum gastrin. Such associations between serological markers and cancer need to be established in a cross sectional study first, as a longitudinal study is much more costly and requires much more time. Whether hypergastrinaemia is just an epiphenomenon of atrophic gastritis or plays a separate part in carcinogenesis by its trophic effect has not as yet been clarified. ${ }^{44}$

In conclusion, the intercountry differences in pepsinogens and gastrin point to a higher prevalence of mild and severe atrophic gastritis in the Japanese than in the Dutch. The $H$ pylori seropositivity rate and thus the prevalence of chronic superficial gastritis is also much higher in Japan than in the Netherlands. The differences in the serological markers of atrophic gastritis exist equally, however, in $H$ pylori negative and positive subjects. Thus, these findings point to the possibility of development of atrophic gastritis independent of $H$ pylori infection in the Japanese population.

We thank the medical services of Shell International and the army in The Hague and Philips in Eindhoven, the Netherlands, and the departments specialising in periodic medical examinations of Hara Sanshin and Saiseikai Hospital and the section gastroenterology of the department of psychosomatic medicine of Kyushu University Hospital in Fukuoka, Japan, for their of Kyush Uniran, for their cooperation, J P Giliams and I Kuiper for their technical assistance, and J Baines for his proofreading. This research was supported by Glaxo Gastroenterology, the Netherlands. Part of this work was presented in abstract form during the Digestive Disease Week of the American Gastroenterological Association in May 1994 (Gastroenterology 1994; 106: A26).

1 Samloff IM, Varis K, Ihamäki T, Siurala M, Rotter JI. Relationships among serum pepsinogen I, serum pepsinogen II, and gastric mucosal histology. A study in relatives of patients with pernicious anemia. Gastroenterology 1982 83: 204-9.

2 Borch K, Axelsson CK, Halgreen H, Damkjaer Nielsen M, Ledin T, et al. The ratio of pepsinogen A to pepsinogen C: a sensitive test for atrophic gastritis. Scand $\mathcal{f}$ Gastroenterol a sensitive test for

3 Haruki K, Kurokawa K, Adachi H, Obata H. Serum and gastric mucosal pepsinogens in atrophic gastritis, particularly in type A gastritis associated with pernicious anemia larly in type A gastritis associated with pernicious
in Japanese. Gastroenterol fpn 1993; 28: 359-66.

4 Westerveld BD, Pals G, Lamers CBHW, Defize J, Pronk JC, Frants RR, et al. Clinical significance of pepsinogen A isozymogens, serum pepsinogen $\mathrm{A}$ and $\mathrm{C}$ levels, and serum gastrin levels. Cancer 1987; 59: 952-8.

5 Bins M, Burgers PICJ, Selbach SGM, van Wettum TB, Lamers CBHW, van Tongeren JHM. The relation between basal gastric $\mathrm{pH}$ and serum gastrin. Digestion 1982; 23: $271-3$ 
6 Varis K, Samloff IM, Ihamäki T, Siurala M. An appraisal of tests for severe atrophic gastritis in relatives of patients with pernicious anemia. Dig Dis Sci 1979; 24: 187-91.

7 Karnes WE, Samloff IM, Siurala M, Kekki M, Sipponen P, Kim SWR, et al. Positive serum antibody and negative tissue staining for Helicobacter pylori in subjects with atrophic body gastritis. Gastroenterology 1991; 101: 167-74.

8 Ihamäki T, Varis K, Siurala M. Morphological, functional and immunological state of the gastric mucosa in gastric carcinoma families. Comparison with a computermatched family sample. Scand $\mathcal{f}$ Gastroenterol 1979; 14: matched
$801-12$.

9 Ihamäki T, Saukkonen M, Siurala M. Long-term observation of subjects with normal mucosa and with superficial tion of subjects with normal mucosa and with superficial gastritis: results of 23-27 years' follow-
Scand f Gastroenterol 1978; 13: 771-5.

10 Correa P, Haenszel W, Cuello C, Zavala D, Fontham E, Zarama G, et al. Gastric precancerous process in a high risk population: cohort follow-up. Cancer Res 1990; 50 4737-40.

11 Ihamäki T, Kekki $M$, Sipponen $P$, Siurala $M$. The sequelae and course of chronic gastritis during a 30- to 34-year bioptic follow-up study. Scand $\mathcal{f}$ Gastroenterol 1985; 20: 485-91.

12 Walker IR, Strickland RG, Ungar B, Mackay IR. Simple atrophic gastritis and gastric carcinoma. Gut 1971; 12: 906-11

13 Strickland RG, Mackay IR. A reappraisal of the nature and significance of chronic atrophic gastritis. Dig Dis Sci 1973, 18: $426-40$.

14 Imai T, Kubo T, Watanabe H. Chronic gastritis in Japanese with reference to high incidence of gastric carcinoma. $f$ Natl Cancer Inst 1971; 47: 179-95.

15 Kato I, Tominaga S, Ito Y, Kobayashi S, Yoshii Y, Matsuura A, et al. A prospective study of atrophic gastritis and stomac

16 Correa P. A human model of gastric carcinogenesis. Cancer Res 1988; 48: 3554-60.

17 Correa $P$. Is gastric carcinoma an infectious disease? $N$ Engl f Med 1991; 325: 1170-1.

18 Forman D, Newell DG, Fullerton F, Yarnell JWG, Stacey AR, Wald N, et al. Association between infection with Helicobacter pylori and risk of gastric cancer: evidence from a prospective investigation. BMF 1991; 302: 1302-5.

19 Parsonnet J, Friedman GD, Vandersteen DP, Chang Y, Vogelman JH, Orentreich $\mathrm{N}$, et al. Helicobacter pylori infection and the risk of gastric carcinoma. $N$ Engl $\mathscr{f} M e d$ 1991; 325: 1127-31.

20 Nomura A, Stemmermann GN, Chyou P-H, Kato I, PerezPerez GI, Blaser MJ. Helicobacter pylori infection and Perez GI, Blaser MJ. Helicobacter pylori infection and gastric carcinoma among Japanese

21 Talley NJ, Zinsmeister AR, Weaver A, DiMagno EP, Carpenter HA, Perez-Perez GI, et al. Gastric carcinoma and Helicobacter pylori infection. $\mathcal{F}$ Natl Cancer Inst 1991 83: 1734-9.

22 Hansson L-E, Engstrand L, Nyrén O, Evans DJ, Lindgren A, Bergström $\mathrm{R}$, et al. Helicobacter pylori infection: independent risk indicator of gastric adenocarcinoma. Gastroenterology 1993; 105: 1098-103.

23 Forman D, Webb P, Newell D, Coleman M, Palli D, Moller $\mathrm{H}$, et al. An international association between Helicobacter pylori infection and gastric cancer. The Helicobacter pylori infection and gastric cancer.
Eurogast Study Group. Lancet 1993; 341: 1359-62.

24 Palli D, Decarli A, Cipriani F, Sitas F, Forman D, Amadori $\mathrm{D}$, et al. Helicobacter pylori antibodies in areas of Italy at varying gastric cancer risk. Cancer Epidemiol Biomarkers Prev 1993; 2: 37-40

25 Howson CP, Hiyama T, Wynder EL. The decline in gastric cancer: epidemiology of an unplanned triumph. Epidemio Rev 1986; 8: 1-27.

26 Schlemper RJ, van der Werf SDJ, Vandenbroucke JP, Biemond I, Lamers CBHW. Peptic ulcer, non-ulcer dyspepsia and irritable bowel syndrome in the Netherlands and Japan. Scand f Gastroenterol 1993; 28 (suppl 200): and Ji. 1 .

27 Peña AS, Endtz HPh, Offerhaus GJA, HoogenboomVerdegaal A, van Duijn W, de Vargas N, et al. Value of serology (ELISA and immunoblotting) for the diagnosis of Campylobacter pylori infection. Digestion 1989; 44: $131-41$.

28 Veenendaal RA, Peña AS, Kuiper I, van Duijn W, Lamers CBHW. Diagnostic value of the local and systemic antibody response to Helicobacter pylori infection [Abstract] Irish $\mathcal{F}$ Med Science 1992; 161 (suppl 10): 76-7.

29 Biemond I, Jansen JBMJ, Crobach LFSJ, Kreuning J, Lamers CBHW. Radioimmunoassay of human pepsinogen $\mathrm{A}$ and pepsinogen $\mathrm{C}$. Eur $¥$ Clin Chem Clin Biochem gen $A$ and pepsino
$1989 ; 27: 19-25$.

30 Biemond I, Kreuning J, Jansen JBMJ, Lamers CBHW. Diagnostic value of serum pepsinogen $C$ in patients with raised serum concentrations of pepsinogen A. Gut 1993; 34: 1315-8.

31 Biemond I, Kreuning J, Jansen JBMJ, Lamers CBHW. Serum pepsinogens in patients with gastric diseases or after gastric surgery. Scand f Gastroenterol 1994; 29: 238-42.

32 Jansen JBMJ, Lamers CBHW. Effect of changes in serum calcium on secretin-stimulated serum gastrin in patients with Zollinger-Ellison syndrome. Gastroenterology 1982; 83: 173-8.

33 Asaka M, Kimura T, Kudo M, Takeda H, Mitani S, Miyazaki $\mathrm{T}$, et al. Relationship of Helicobacter pylori to serum pepsinogens in an asymptomatic Japanese population. Gastroenterology 1992; 102: 760-6.

34 Kuipers EJ, Uyterlinde AM, Nelis GF, Meijer CJLM, Peña AS, Meuwissen SGM. Long term follow up of Helicobacter pylori associated gastritis [Abstract]. Gastroenterology 1994; 106: A113.

35 Nomura A, Yamakawa $H$, Ishidate $T$, Kamiyama $S$, Masuda H, Stemmermann GN, et al. Intestinal metaplasia in Japan: association with diet. $\mathcal{f}$ Natl Cancer Inst plasia in Japan:

36 Villako K, Maards H, Tammur R, Keevalik R, Peetsala M Sipponen $\mathrm{P}$, et al. Helicobacter (Campylobacter) pylori infestation and the development and progression of chronic gastritis: results of long-term follow-up examinations of a random sample. Endoscopy 1990; 22: 114-7.

37 Satoh K, Kimura K, Yoshida Y, Taniguchi Y, Kasano T, Kihira $\mathbf{K}$, et al. Helicobacter pylori infection and the extension of atrophic gastritis. European fournal of Gastroenterology and Hepatology 1993; 5 (suppl 1): S115-7.

38 Haenszel W, Kurihara M. Studies of Japanese migrants. I. Mortality from cancer and other diseases among Japanese in the United States. F Natl Cancer Inst 1968; 40: $43-68$.

39 Kohli Y, Pfeiffer CJ, Kutty KP, Barrowman JA, Heughan C, Kepkay DL. Endoscopic diagnosis of intestinal metaplasia in Canada and Japan. $\mathcal{F}$ Clin Gastroenterol 1981; 3 (suppl 1): 29-33.

$40 \mathrm{Kimura} \mathrm{K}$. Chronological transition of the fundic-pyloric border determined by stepwise biopsy of the lesser and greater curvatures of the stomach. Gastroenterology 1972; 63: 584-92.

41 Villako K, Kekki M, Tamm A, Tammur R, Savisaar E, Viirsalu V, et al. Epidemiology and dynamics of gastritis in a representative sample of an Estonian urban population. Scand $¥$ Gastroenterol 1982; 17: 601-7.

42 Cheli R, Simon L, Aste H, Figus IA, Nicoló G, Bajtai A, et al. Atrophic gastritis and intestinal metaplasia in asymptomatic Hungarian and Italian populations. Endoscopy 1980; 12: $105-8$

43 Mossi S, Meyer-Wyss B, Renner EL, Merki HS, Gamboni $G$, Berglinger C. Influence of Helicobacter pylori, sex, and age on serum gastrin and pepsinogen concentrations in subjects without symptoms and patients with duodenal ulcers. Gut 1993; 34: 752-6.

44 Waldum HL, Petersen H, Brenna E. Gastrin and gastric cancer. European fournal of Gastroenterology and Hepatology 1992; 4: 801-11. 